\begin{tabular}{c} 
Volume and Issues Obtainable at Center for Sustainability Research and Consultancy \\
Journal of Business and Social Review in Emerging Economies \\
ISSN: 2519-089X (E): 2519-0326 \\
Volume 5: No. 1, June 2019 \\
JSRᄃ \\
Journal homepage: www.publishing.globalcsrc.org/jbsee \\
\hline
\end{tabular}

\title{
Enhancing Student Competencies Through Digital Video Production: A Project- based Learning Framework
}

\author{
${ }^{1}$ Lim Seh Hoe, ${ }^{2}$ Tay Choo Chuan, ${ }^{3}$ Hanipah Hussin, ${ }^{4}$ Pang Yee Jiea \\ ${ }^{1}$ Azman 1Institute of Technology Management \& Entrepreneurship, Universiti Teknikal Malaysia Melaka, Hang \\ Tuah Jaya, 76100 Durian Tunggal, Melaka, Malaysia, limsehhoe@gmail.com \\ ${ }^{2}$ Faculty of Electrical Engineering, Universiti Teknikal Malaysia Melaka, Hang Tuah Jaya, 76100 Durian Tunggal, \\ Melaka, Malaysia, tay@utem.edu.my \\ ${ }^{3}$ Centre for Languages and Human Development, Universiti Teknikal Malaysia Melaka, Hang Tuah Jaya, 76100 \\ Durian Tunggal, Melaka, Malaysia, hanipah@utem.edu.my \\ ${ }^{4}$ Institute of Technology Management \& Entrepreneurship, Universiti Teknikal Malaysia Melaka, Hang Tuah Jaya, \\ 76100 Durian Tunggal, Melaka, Malaysia, yeejiea@gmail.com
}

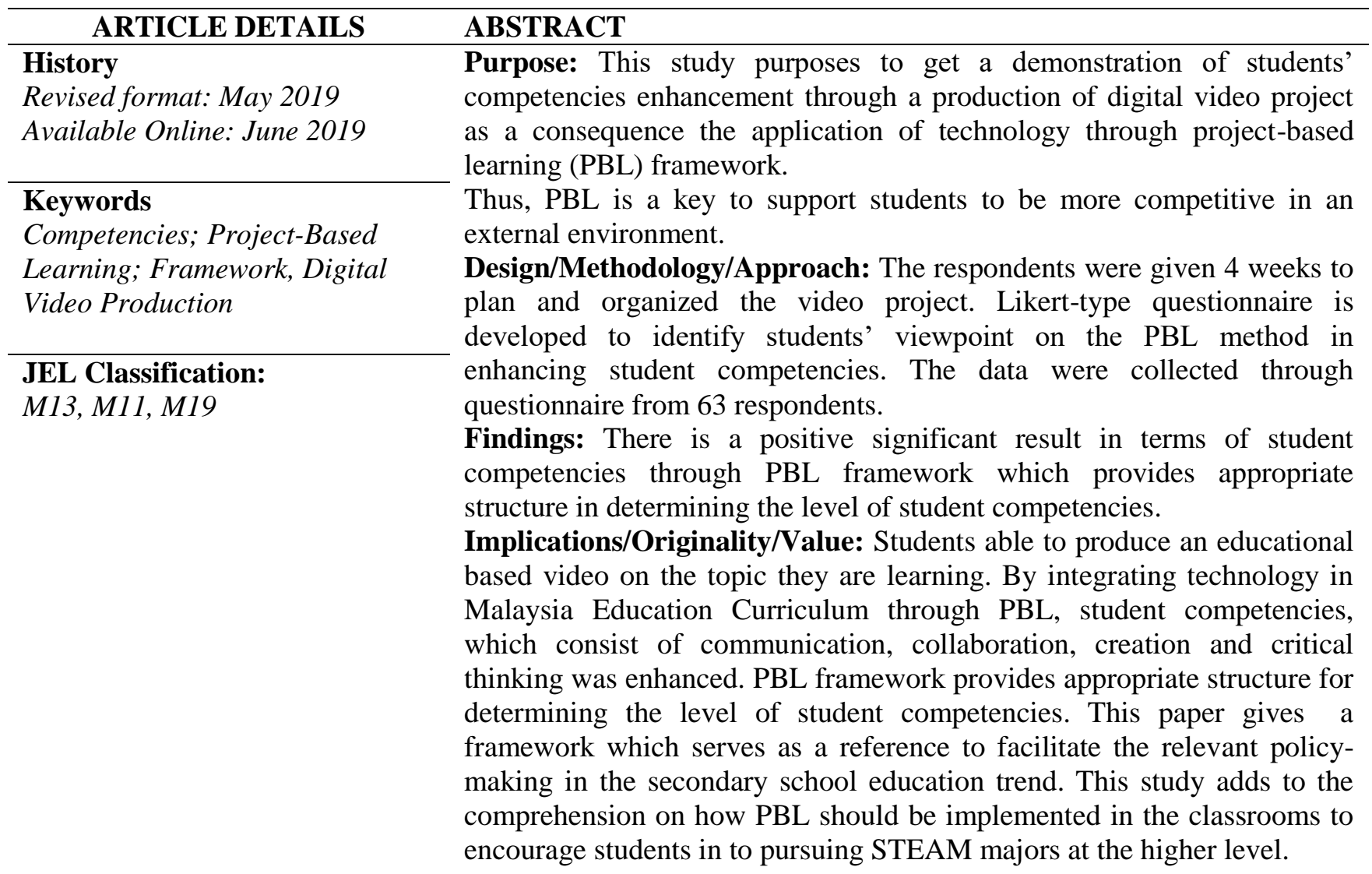

(C) 2019 The authors, under a Creative Commons Attribution-

NonCommercial 4.0

Corresponding author's email address: limsehhoe@gmail.com

Recommended citation: Hoe, L. S., Chuan, T. C., Hussin, H. and Jiea, P. Y. (2019). Enhancing student competencies through digital video production: A Project-based learning framework. Journal of Business and Social Review in Emerging Economies, 5 (1), 51-62

DOI: $10.26710 /$ jbsee.v5i1.508 


\section{Introduction}

According to the "Future of Jobs" report from World Economic Forum, complex problem-solving, critical thinking and creativity will be the main abilities employers expect of laborers in 2020. In present worldwide economy, a country's prosperity depends fundamentally on the knowledge, skills and competencies of students as previous study (Malaysia Education Blueprint, 2013). The current educational quality development should change from merely meeting the knowledge and the graduation requirements to a high-level competency. There is a essential to improve students' competencies for 21 st century era in order to maintenance the change of universal competition and challenging in the digital world of workplace as previous study (Soparat, Arnold, \& The, 2015). Language learning ought to comprise the psychomotor and affective perspectives supported by innovation as a arrangement to proceed with education at a high level and build up student's competencies for future. The Malaysian educational system is currently undergoing transformation, one emphasis of which is to create a generation who can communication, collaboration, think creatively, innovatively and critically. This educational program will even now pressure student-centered and differentiated instructing, yet have a more emphasis on project-based work. Schoolbased assessments will likewise move their concentration to testing for higher-order thinking ability. (Malaysia Education Blueprint, 2013). Thus "transmission pedagogy" has formed high-achieving and efficient student, it has claimed that students should be shaped in their creativity, flexibility and high performance workforce for Malaysia to meet the global economic challenges.

School have to provide the opportunity for secondary students a more student-centered, active, engaging and productive role in integration complex learning activities, such as project-based learning(PBL), that reflect the kind of learning approach which students will engage outside of school ((Edmunds, Arshavsky, Glennie, Charles, \& Rice, 2017; Asghar, Ellington, Rice, Johnson, \& Prime, 2012; Larmer \& Mergendoller, 2010). PBL able to increase student motivation by organizing their own learning in solving real-world problems. Existing research that how that PBL is an essential instruction approach that enables students to improve in learning content knowledge, adapt and develop skills necessary for future success. ("Framework for High Quality Project Based Learning," 2017) Students develop competencies in generating new ideas and products as well as able to work with a variety of technologies as previous study (Dole et al., 2016). Today, students are comfortable integrating technology which is an educational essential piece, not just as entertainment but should be done effectively in learning to enhance student competencies. Beside this, video can be part of the immersive simulation environments; can be installed in increasingly complex virtual learning environment with content, pictures, illustrations, and so on as previous study. (Rasi \& Poikela, 2016). This study focus on producing a video about subject matter as learning process. Secondary students will learn content, meanwhile the transferable competencies such as creativity, collaboration and problem solving desired in video production. (Pirhonen \& Rasi, 2017; Hakkarainen 2009;2007; Shewbridge and Berge 2004; Jonassen et al. 2003; Jonassen 2000; Verran 1992) A study found the creating video project sincerely extremely positive and respected it propelling to deal with a video which they realized will have use in the future. This exploration recommends that a multimodal video project in a higher education setting enhances learning through increased motivation and positive emotions.

A major challenge for instruction to frame on our better comprehension of experiential learning for the plan of novel environments that are helpful to encouraging in all secondary student communication and collaborative learning skills, profitable and transferable information, and a disposition toward able thinking and critical thinking. A few endeavors to realize the aim of the quality education that incorporate the component are appropriate learning approach one of them learning framework. The transformation framework as a model for the design of secondary education project based learning planned to be dominant in inspiring in students learning processes that encourage the securing of deeper learning. This study was instrumental in distinguishing and indicating the diverse components of the model to enhance student competencies.

The framework is aimed to assist future leaders in providing a progressively total, all encompassing, systematic and sustainability education. In order to develop a superior attitudes and activities of future generations, we need to provide students with an entire arrangement of sustainability competences. PBL framework as shown in Figure 1, is ultimately serve as a guide for students and educators to fulfil their need, moreover to achieve desired educational outcomes in student competencies 


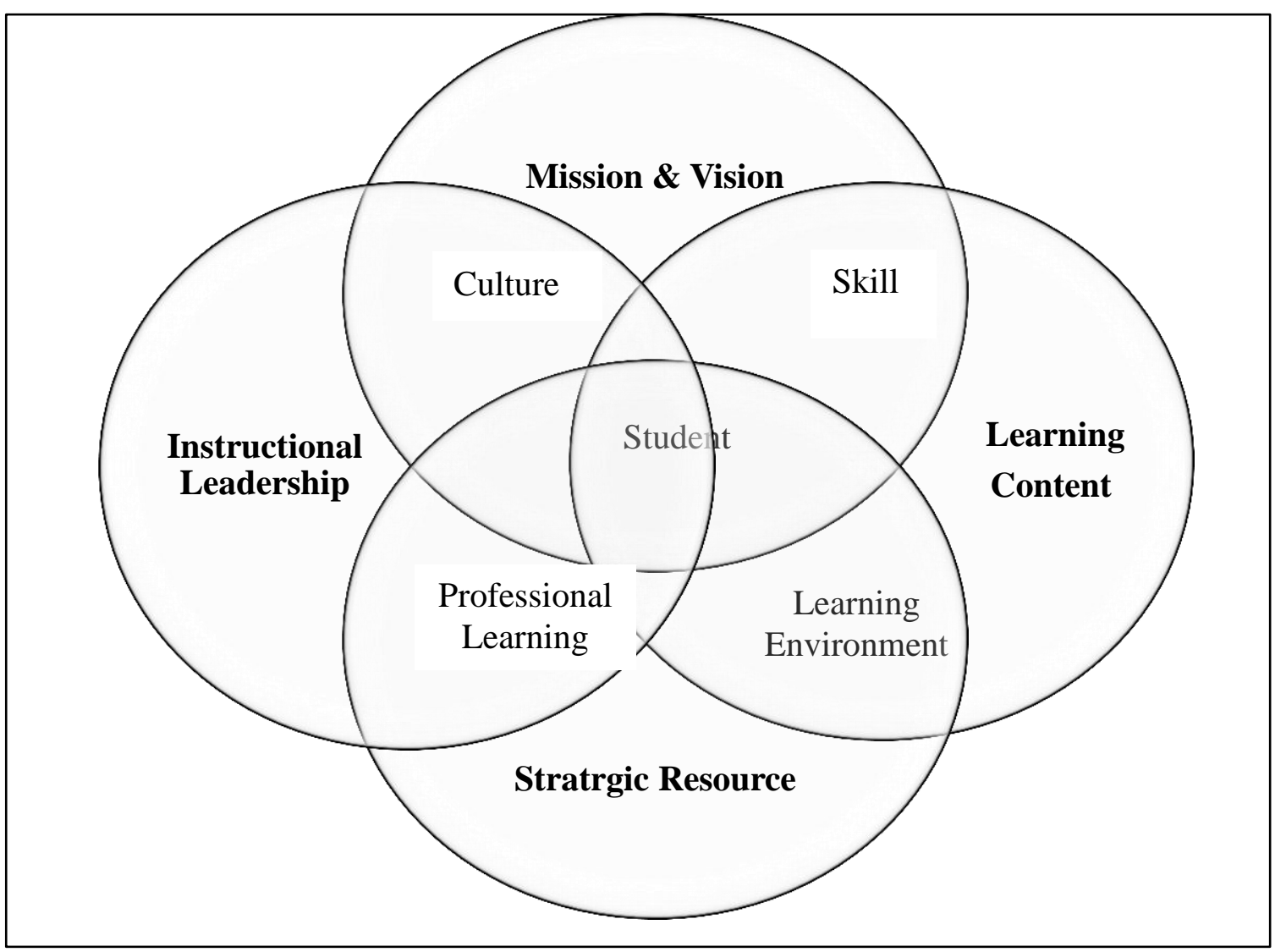

Figure 1 Adopted from Transformational framework in effecting whole school change (Hendry, Hays, Challinor, \& Lynch, 2017)

Framework of PBL highlighted the key organizational structure as Table 1, however element of framework of PBL shown in Table 2.

Table 1 Key organizational of framework of PBL

\begin{tabular}{|c|c|c|c|}
\hline Mission & $\begin{array}{l}\text { Instruction } \\
\text { Leadership }\end{array}$ & Strategic Resource & $\begin{array}{l}\text { Learning } \\
\text { Content }\end{array}$ \\
\hline $\begin{array}{l}\text { Student have have a strong senseof } \\
\text { wellbeing. } \\
\text { Student are affective } \\
\text { communicators. } \\
\text { Student are confident and involved } \\
\text { learners } \\
\text { Student are concerned with and } \\
\text { contribute totheir world }\end{array}$ & $\begin{array}{l}\text { Profesional } \\
\text { Learning Team } \\
\text { Adminstrator } \\
\text { Instructionnal } \\
\text { Walks } \\
\text { Individual }\end{array}$ & $\begin{array}{l}\text { Appropriate use of } \\
\text { device } \\
\text { Wireless } \\
\text { infrastruture } \\
\text { Learning } \\
\text { management } \\
\text { system } \\
\text { Text book }\end{array}$ & $\begin{array}{l}\text { Culture } \\
\text { Team building } \\
\text { Responsible } \\
\text { life }\end{array}$ \\
\hline
\end{tabular}

Table 2 Element of framework of PBL

\begin{tabular}{|l|l|l|l|}
\hline Culture & Professional Learning & Learning Environment & Entrepreneur skill \\
\hline $\begin{array}{l}\text { Peer-coaching } \\
\text { Student-centered } \\
\text { Group work }\end{array}$ & Timetable & Classroom & Communication \\
Development program & $\begin{array}{l}\text { Computer lab } \\
\text { Home }\end{array}$ & presentation \\
\hline
\end{tabular}


This framework will assist students to become future leaders as well as citizens who are knowledgeable and understand the natural of world environment. Procedural and conceptual learning are vital and essential tools in improving learning at the secondary school level.

The following model is used in conducting students' PBL

1. Engagement: The problem is presented to challenge the students, activates prior knowledge in brainstorming and their roles are explained.

2. Inquiry/Investigation: With existing knowledge and information to release problem statement, students need to investigate and acquire up to date with scaffolder activities and best information to conduct the project.

3.Issue Resolution: Students analyze their options and settle on an activity or a choice.

4.Debriefing: Group presentation and discuss not only the substance they have learned and how it may be valuable in new situations yet in addition the procedures engaged in solving the problem.

A few studies have investigated impact of PBL model in knowledge transfer instructional approach. According Beckett (2006), most of these have been conducted in subject-matter classes, while examination on project-based learning in the field of second and foreign language learning is limited (Petersen \& Nassaji, 2016). Furthermore, very few studies have directly compared both lower secondary student and upper secondary student competencies toward PBL. Thomas defined PBL focus is how to achieve the goal on peer collaboration on challenging questions or problems as starting of the flow of project process, that encompass students in design, critical thinking, basic leadership, or expository exercises; give an autonomous chance to work with peer; and conclude in project products or presentations" (Petersen \& Nassaji, 2016; Thomas, 2000)

The current study set out to investigate PBL as an approach use in Chinese Language classroom. The aim of this study to provide a framework to assess whether students' video production could be utilized to enhance secondary student competencies. The study is based on competencies of secondary school students who participated in the producing video. The research questions addressed were as follows:

i. What are the level of student competencies in PBL class room?

ii. Is there any difference competencies level between lower secondary school students and upper secondary school students using PBL framework?

iii. Is there any difference level of the student competencies between male students and female students?

\section{Methodology}

A study was conducted to identify the processes involved when applying the PBL approach. The students were given 4 weeks to plan and organize the video project. This study using the Extended Professional Development Project-based Learning questionnaire designed by Hixson et. al. (2012) to measure the secondary students' competencies following their project-based learning experience. Then, using SPSS version 23, an independent sample t-test was computed to compare the mean difference and its significance based on statistical cut points.

\subsection{Sample}

The target sample for this study was secondary school students that have endured project -based learning practice in production video project. In this study, there are 63 students from secondary school in Melaka as respondents of this study. They are 32 upper secondary school students and 31 lower secondary school students. The essential to study the different secondary form were to get the overall picture of the levels of competencies among secondary education students representing the upper and lower secondary student in Melaka. The instrument was distributed to the students through the researcher as a facilitator PBL. From the 65 questionnaires administered, an overall of 63 questionnaires were returned, indicating $96.9 \%$ in response rate. There were appropriate questionnaires which were from 36 female students and 27 male student.

\subsection{Instrument}

This study was conduct to collect qualitative ordinal data. Likert-type questionnaire is developed to identify students' point of view on the PBL method in enhancing student competencies scales. The standard tests of which the items were taken form has 0.86 average reliability value. This indicates that the items are consistent. The test contained two parts. The first part was on demography and the next part was on assessing the competencies of the students. 
The PBL survey instrument is use as a tool for primary data collection. The data was collected through the use of structured questionnaire which consists of questions on demographics and 22 elements of competencies in critical thinking competency (6 elements), collaborative competency (5 elements), communication competency (5 elements) and creativity competency (6 elements). Each of this element was measured on a 5 point Likert scale, ranging from $1=$ strongly not agree to $5=$ strongly agree. These items were adapted from Hixson et.al. (Hixson, Ravitz, Whisman, \& Hixson, Nate; Ravitz, Jason; Whisman, 2012). To look at the level of interpretation as reported by respondents, mean score for each indicator was calculated. The scale score had a range of 1 to 5 . The number of cells were minimized to interpret the results easily, the scores were recoded into levels of "low" interpretation, "moderate" interpretation, and "high" interpretation. 1 to 2.33 scored "low," 2.34 to 2.66 was considered "moderate" interpretation, and 2.67 to 5.00 was considered "high" interpretation. (Wan Mohamed \& Omar, 2010). Table 3 shows the mean score illustration that is used to compare the competencies level among the secondary students which is used in analyzing descriptive statistics and inferential statistics.

Table 3 illustrates the mean scores for each research question and their levels of competency score analysis.

\begin{tabular}{cl}
\hline Mean Score & Interpretation \\
\hline $1.00-2.33$ & \multicolumn{1}{c}{ Low } \\
$2.34-3.66$ & Moderate \\
$3.67-5.00$ & High \\
\hline
\end{tabular}

In this study, a reliability scale test was carried out for all element in order to evaluate the internal consistency of variables. Based on a reliability index, the value of Cronbach's Alpha was classified in which $0.90-1.00$ is very high, $0.70-0.89$ is high, $0.30-0.69$ is moderate, and $0.00-0.30$ is low.(Nayan, Mahat, Hashim, Saleh, \& Norkhaidi, 2018, Babbie, E. 1992) ). The internal consistency of the enhancing secondary students' competencies Questionnaire was high with a Cronbach's alpha coefficient of $0.86(>0.7)$ indicating good item reliability in the items of students' competencies Questionnaire.

\section{Finding and discussion}

This section discusses the result of the study by analye the responses of students' questionnaire which consists of 63 respondents. The discussion will feature the significant findings in Section A, B. C and D, to be specific critical thinking, collaborative learning, communication and creativity respectively. The result of the descriptive analysis can be presented in the Table 3. The following evaluation scale, in view of the Likert scale utilized in the questionnaire was utilize to interpret the mean value.

\subsection{Qualitative Ordinal Findings from questionnaire}

The quantitative findings present the data from the questionnaire in relation to enhance students' competency towards project-based learning for digital video production in Chinese language activities. 22 items in questionnaires were used to determine "enhancing student competency". A five-point scale was utilized to determine responses.

For answering the research questions, the items for each section of competencies on project-based Learning framework are separate according to type of competency, and statistically analyzed using mean scores, based on levels of mean scores analysis. Critical thinking, communication, collaborative learning and creativity as student's competencies will be considered as low, moderate, or high competency score based on the following value as illustrated in the table 3. The finding regarding the level of student competencies based on secondary education category are discussed according to the data analysis which are descriptive statistics and inferential statistics.

Table 4 The Levels student critical thinking through digital video production on project based learning framework. 
Critical Category

\begin{tabular}{|cl|l|l|l|l|}
\hline & & Frequency & Percent & Valid Percent & $\begin{array}{l}\text { Cumulative } \\
\text { Percent }\end{array}$ \\
\hline Valid & Moderate & 40 & 63.5 & 63.5 & 63.5 \\
& High & 23 & 36.5 & 36.5 & 100.0 \\
& Total & 63 & 100.0 & 100.0 & \\
\hline
\end{tabular}

For the level of effectiveness in enhancing student competency on PBL through digital video production, there are 6 critical thinking competency elements that are made in the study instrument made on the PBL, critical thinking competency elements of item 1 (analyze competing arguments, perspective to a issue), item 2 (create persuasive argument based on supporting evidence), item 3 (create interpretation from reading), item 4 (solve problem by multi solution), item 5 (draw own conclusion based on analysis of facts), and item 6 (compare information from different source). The frequency of means score on critical thinking can be seen in the critical category from Table 4. It shows 40 respondents or $63.5 \%$ in moderate level and 23 respondents or $36.5 \%$ in high level. This mean 63.5 $\%$ of respondents in mean score 2.34 to 3.66 and $36.5 \%$ of respondents in mean score 3.66 to 5.00 .

Similar to the research of collaborative learning, there are 5 collaboration competency elements that are made in the study instrument made on the PBL, collaboration competency elements of item 1 (work in group to complete a task together), item 2 (work as a team to incorporate feedback on group task), item 3

Table 5 The Levels student collaborative learning through digital video production on project based learning framework

\section{Collaborative Category}

\begin{tabular}{|ll|l|l|l|l|}
\hline & Frequency & Percent & Valid Percent & $\begin{array}{l}\text { Cumulative } \\
\text { Percent }\end{array}$ \\
\hline Valid & Low & 2 & 3.2 & 3.2 & 3.2 \\
& Moderate & 23 & 36.5 & 36.5 & 39.7 \\
High & 38 & 60.3 & 60.3 & 100.0 \\
Total & 63 & 100.0 & 100.0 & \\
\hline
\end{tabular}

(work with group set goals and create plan), item 4 (joint products using contributions from member), and item 5 (present group product to the class). The frequency of means score on collaborative learning can be seen in the collaboration category from Table 5. It shows 2 respondents or 3.2\% in low level, 23 respondents $36.3 \%$ in moderate level and 38 respondents or $60.3 \%$ in high level. This mean $3.2 \%$ of respondents in mean score 1.00 to $2.33,36.5 \%$ of respondents in mean score 2.34 to 3.66 and $60.3 \%$ of respondents in mean score 3.66 to 5.00.

Table 6 The Levels student communication through digital video production on project based learning framework

\begin{tabular}{|ll|l|l|l|l|}
\hline & Frequency & Percent & Valid Percent & $\begin{array}{l}\text { Cumulative } \\
\text { Percent }\end{array}$ \\
\hline Valid & Low & 2 & 3.2 & 3.2 & 3.2 \\
& Moderate & 39 & 61.9 & 61.9 & 65.1 \\
High & 22 & 34.9 & 34.9 & 100.0 \\
Total & 63 & 100.0 & 100.0 & \\
\hline
\end{tabular}


This study demonstrates there are 5 communication competency elements that are made in the study instrument made on the PBL, communication competency elements of item 1 (decide how to present their group work), item 2 (prepare and deliver oral presentation to others), item 3 (able to answer in front of audience), item 4 (known to convey idea using media other than a written paper), and item 5 (use structure data for use in written products or oral presentations. The frequency of means score on communication can be seen in the communication category from Table 6. It shows 2 respondents or $3.2 \%$ in low level, 39 respondents $61.9 \%$ in moderate level and 22 respondents or $34.9 \%$ in high level. This mean $3.2 \%$ of respondents in mean score 1.00 to $2.33,61.9 \%$ of respondents in mean score $2.34-3.66$ and $34.9 \%$ of respondents in mean score $3.66-5.00$.

Table 7 The Levels student creativity through digital video production on project based learning framework

\section{Creativity Category}

\begin{tabular}{|ll|l|l|l|l|}
\hline & Frequency & Percent & Valid Percent & $\begin{array}{l}\text { Cumulative } \\
\text { Percent }\end{array}$ \\
\hline Valid & Low & 2 & 3.2 & 3.2 & 3.2 \\
& Moderate & 40 & 63.5 & 63.5 & 66.7 \\
& High & 21 & 33.3 & 33.3 & 100.0 \\
Total & 63 & 100.0 & 100.0 & \\
\hline
\end{tabular}

The finding of study shows there are 6 creativity competency elements that are made in the study instrument made on the PBL, creativity competency elements of item 1 (invent a solution to a complex, open-ended question or problem), item 2 (test out different idea and self-directed to improve work), item 3 (generate idea to confront problem), item 4 (create original product to express self-ideas), item 5 (use idea creation), and item 6 (have learned creativity and innovation). The frequency of means score on creativity can be seen in the creativity competency category from Table 7. It shows 2 respondents or $3.2 \%$ in low level, 40 respondents $63.5 \%$ in moderate level and 21 respondents or $33.3 \%$ in high level. This mean $3.2 \%$ of respondents in mean score 1.00 to $2.33,63.5 \%$ of respondents in mean score $2.34-3.66$ and $33.3 \%$ of respondents in mean score $3.66-5.00$.

For the high level of effectiveness in enhancing student competency on PBL through digital video production. As Figure 2 shows, the comparison among four competencies indicates critical thinking $36.5 \%$, collaborative learning $60.3 \%$, creativity $33.3 \%$, and communication $34.9 \%$ in high level achievement through digital video production on project based learning framework. These results found that among respondents, majority believe that digital video production in PBL to enhance their competencies regard collaboration, compare with critical thinking, creativity and communication. Data is given for four weeks according to project based learning at group. Students were provided numerous opportunities to engage in high level thinking over extended period of time. Group presentation able deliver students chance to collaborate, clarify and validate their thinking. The finding provide evidence for our framework of PBL as a specific learning for secondary school.

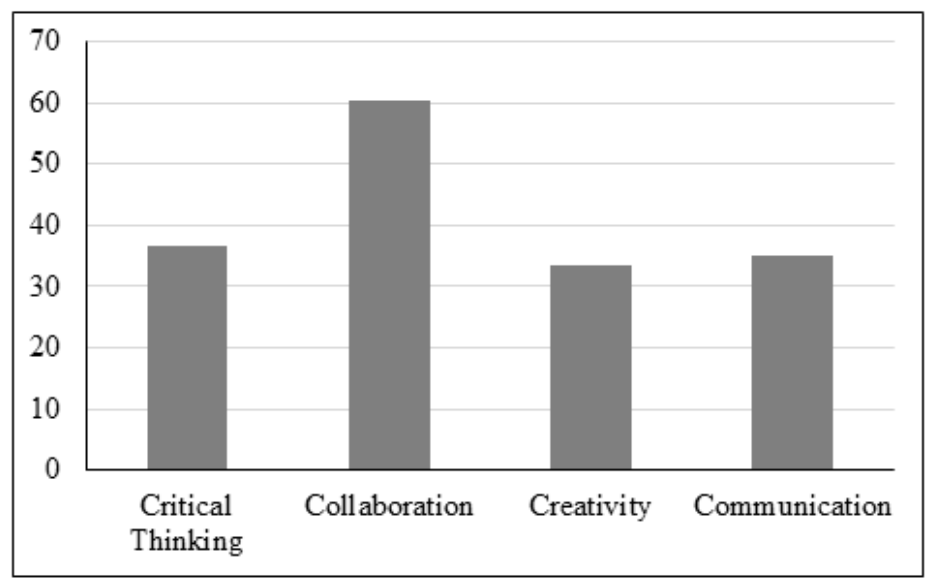


Figure 2 The levels of high achievement in four competencies through digital video production on project based learning framework.

The purpose of the study was to inspect the effect of the production of digital video on project-based learning framework in developing secondary student' competency. The analysis of the results indicates that the production of digital video on project-based learning framework has a significant influence in improving students' competencies within the element of critical thinking, collaboration learning, communication and creative. The results from the questionnaires study support to this conclusion. From these results it emerges that the production digital video on project-based learning can be considered as a teaching effectively approach in secondary school. In the four competency elements, which are critical thinking, collaborative learning, communication and creativity, the student competencies demonstrated statistically significant high level that can contribute to a successful competency in project based learning.

Next, to analyze each student's mean score for every competency, the total of the value to each dimension in that competency was divided by the number of that dimension of competency. Table 8 indicates the mean scores and standard deviation of the four dimension of secondary student competencies in PBL classroom.

Table 8 The Result of descriptive statistic for enhancing four competencies through digital video production on project based-learning

\begin{tabular}{lllll}
\hline No. & Student Competencies & Mean & $\begin{array}{l}\text { Standard } \\
\text { Deviation }\end{array}$ & Interpretation \\
\hline 1. & Critical Thinking & 3.70 & 0.41 & High \\
\hline 2. & Collaboration & 3.77 & 0.67 & High \\
\hline 3. & Creativity & 3.44 & 0.64 & Moderate \\
\hline 4. & Communication & 3.53 & 0.49 & Moderate \\
\hline
\end{tabular}

Table 8 shows the overall score mean secondary school students in Alor Gajah, Melaka to the different dimensions of competencies from 3.44.to 3.77 on a 5-point Likert-type rating scale. The results present that on average, the respondents exhibited high and moderate levels of 4Cs (critical thinking, collaboration, communication and creativity) competencies. Results suggests that critical thinking and collaboration were enhanced high level by production video project whereas communication and creativity were enhanced high level by production video project. Students develop higher order thinking by a process of production digital video, students become effective communicators, collaborators.

Based on the findings indicate the dimension of collaboration had a total mean of the highest enhancement competency (mean score $=3.77$, standard deviation $=0.67$ ), followed by dimension of critical thinking (mean score $=3.70$, standard deviation=0.41), next the dimension of communication (mean score $=3.53$, standard deviation=0.49), and finally the dimension of creativity was the lowest enhancement competency. (mean score $=$ 3.44 , standard deviation=0.64). This reflects the level of student competencies of the secondary school students of Alor Gajah, Melaka is to be at a high level and tend to collaborative learning and critical thinking.

As Table 8 shows, most student believed that project based learning had highly enhanced them in collaborative learning and critical thinking via producing video project. However, secondary students less communication among peer while implemented PBL. Student competencies level of secondary school students in Melaka by secondary education level based on four dimensions: Critical thinking, collaboration, communication, creativity.

Table 9 Paired samples t-test of student competencies of lower secondary and upper secondary

\begin{tabular}{llllllll}
\hline No & $\begin{array}{l}\text { Student } \\
\text { Competencies }\end{array}$ & $\begin{array}{l}\text { Mean } \\
\text { (Lower Form) }\end{array}$ & SD & $\begin{array}{l}\text { Mean } \\
\text { (Upper Form) }\end{array}$ & SD & T value & Sig. \\
\hline 1. & Critical Thinking & 3.55 & 0.28 & 3.84 & 0.48 & -2.67 & 0.01 \\
\hline 2. & Collaboration & 3.55 & 0.62 & 3.98 & 0.66 & -2.75 & 0.01 \\
\hline 3. & Creativity & 3.45 & 0.46 & 3.61 & 0.51 & -1.22 & 0.23 \\
\hline 4. & Communication & 3.28 & 0.49 & 3.57 & 0.72 & -1.87 & 0.72 \\
\hline
\end{tabular}


The objective of this study was to gauge whether there was a significant difference among four competencies of student in lower secondary and upper secondary. Enhancing student competencies in production digital video project. With this, PBL has enabled students to work collaboration and solve problem by critical thinking on their idea, and encourage them to be more creativity and innovative in learning.

Table 9 describes enhancing competencies of secondary students on each dimension can be known from the mean score obtained by secondary students on lower secondary students and upper secondary students. The number questions used consists of 22 item with 5-point Likert scale. The lowest secondary student in critical thinking, collaboration and creativity of enhancing competencies in moderate category, between mean score 3.45 to 3.55. However, communication competency in low category with mean score 3.28. Whereas The upper secondary student in critical thinking and collaboration of enhancing competencies in high category with mean score 3.84 and 3.98. However, creativity and communication competencies in moderate category with mean score 3.61and 3.57.

The paired-samples t-test was conducted to determine whether student competencies had higher scores upper secondary than lower secondary. The finding in Table 9 indicates that there was highly statistically significant difference between the scores of the upper secondary students and lower secondary student in critical thinking and collaboration competency. From Table 9 it can be seen that the dimension of critical thinking for upper secondary, had an average of (mean score $=3.84$ ) which was higher score than lower secondary students (mean score $=3.55$ ) and with the $\mathrm{p}$-value of 0.01 . The paired samples t-test reveal that upper secondary students scores were higher in critical thinking. (mean score $=3.84$, standard deviation $=0.48$ ) compared to lower secondary students (mean score $=3.55$, standard deviation $=0.28), \mathrm{t}(32)=-0.26, \mathrm{p} \leq 0.05$.

Additionally, for the dimension of collaboration competency, the upper secondary students had an average score for collaboration competencies had an average of (mean score $=3.98$ ) which was higher score than lower secondary students (mean score $=3.55$ ) and with the p-value of 0.01 . The paired samples t-test reveal that upper secondary students scores were higher in collaborative learning. (mean score $=3.98$, standard deviation $=0.66$ ) compared to lower secondary students (mean score $=3.55$, standard deviation $=0.62$ ), $\mathrm{t}(32)=-0.75, \mathrm{p} \leq 0.05$.

The result showed that the upper secondary students have higher score in critical thinking and collaborative learning than lower secondary students. Therefore, hypothesis upper secondary students have higher score in critical thinking and collaborative learning than lower secondary students, is not rejected.

The finding in Table 9 indicates that there was no significant difference between the scores of the upper secondary students and lower secondary student in creativity and communication competency. From Table 9 it can be seen that the dimension of creativity competency for upper secondary, had an average of (mean score $=3.61$ ) which was higher score than lower secondary students (mean score $=3.45$ ) and with the p-value of 0.23 . The paired samples ttest reveal that upper secondary students scores were higher in critical thinking. (mean score $=3.61$, standard deviation $=0.51$ ) compared to lower secondary students (mean score $=3.45$, standard deviation $=0.46), \mathrm{t}(32)=-$ $1.22, \mathrm{p} \geq 0.05$.

Additionally, for the dimension of communication competency, the upper secondary students had an average score for communication competencies had an average of (mean score $=3.57$ ) which was higher score than lower secondary students (mean score $=3.28$ ) and with the p-value of 0.72 . The paired samples t-test reveal that upper secondary students scores were higher in communication. (mean score $=3.57$, standard deviation $=0.72$ ) compared to lower secondary students (mean score $=3.28$, standard deviation $=0.49$ ), $\mathrm{t}(32)=-1.87, \mathrm{p} \leq 0.05$.

The result showed that the upper secondary students have similarity score in creativity and communication than lower secondary students. Therefore, hypothesis upper secondary students have higher score in creativity and communication than lower secondary students, is rejected.

In general, the statistical values indicate that upper secondary students in critical thinking and collaboration competencies mean scores significantly higher score than the lower secondary students. Thus, it is possible to say that upper form students' critical thinking and collaboration competencies determine PBL success enhancing upper secondary school students' critical thinking and collaboration competencies highly. However, communication and creativity differences between the two groups is statistically no significant. Thus, the statistical values indicate that 
upper secondary students in communication and creativity mean scores no significantly lower score than the lower secondary students. Thus, it is possible to say that lower and upper secondary students' communication and creativity competencies determine PBL success enhancing lower and upper secondary school students' communication and creativity competencies similarity.

The above graph presents the bar chart representations of the competencies mean scores of the secondary students. There are the groups in the horizontal line: critical thinking, collaboration, creativity and communication. Each of them has two bar that represent the two dimensions of student: lower secondary students and upper secondary students. And, the vertical line indicates the mean scores. Therefore, the four dimensions' lower secondary students' competencies are low when compare with upper secondary students.

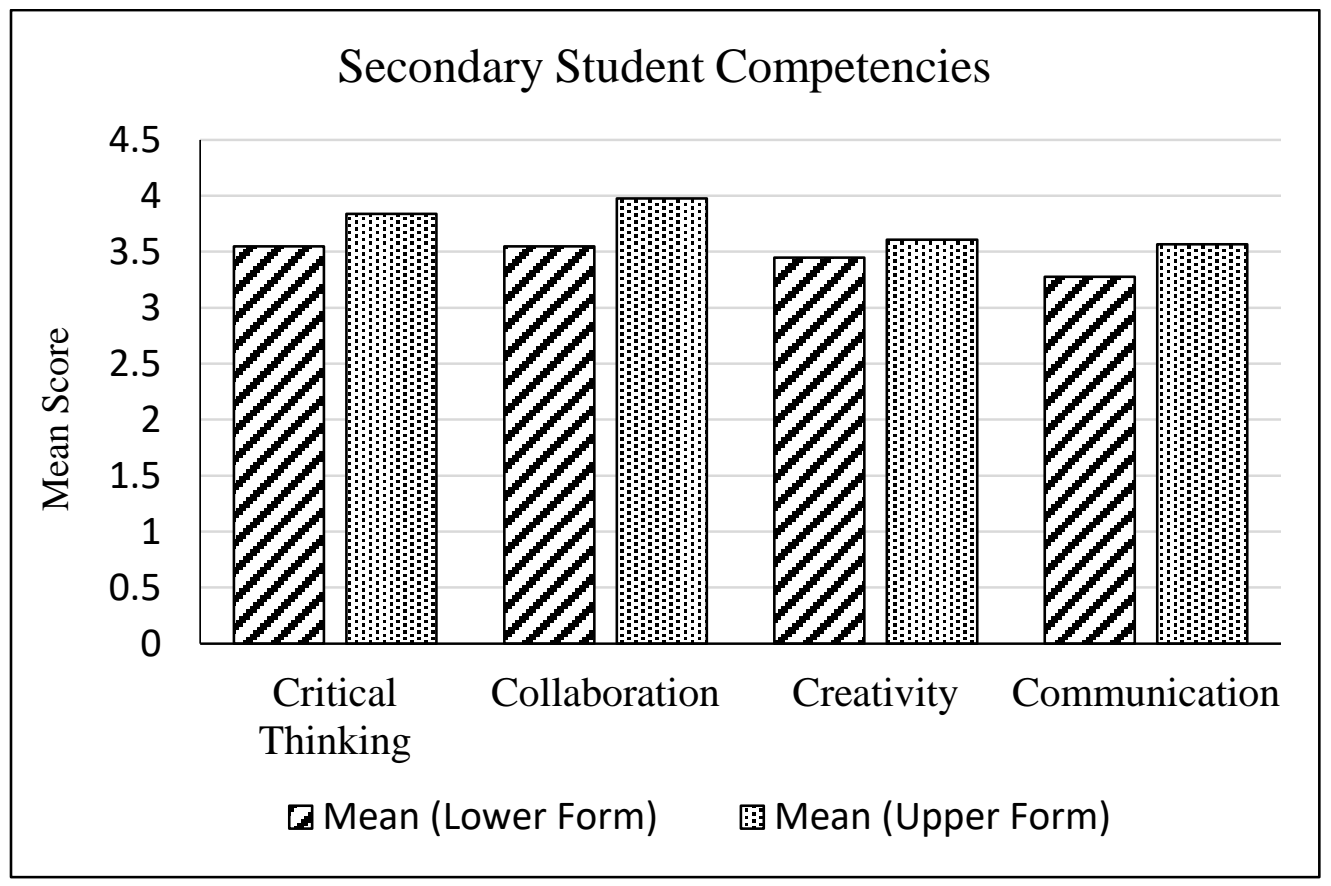

Fig. 2: Graphic Representation of Secondary Student Competencies Literacy Scores

Nevertheless, student competencies determine students' collaboration competency is the most enhancement level (0.43). Critical thinking and communication more enhancing than creativity as the mean differences between the dimension is greater in critical thinking and communication competencies (0.30) than in creativity competency (0.16).

The secondary student collaboration competency has the highest difference mean score with 0.43 . This indicates that secondary upper students are able to collaborate with peer in PBL The creativity competency has the lowest difference mean score with 0.09 .

Table 10 Comparisons between male and female student on the level of 4Cs competencies on project based learning

\begin{tabular}{|c|c|c|c|c|c|c|c|c|c|}
\hline No & $\begin{array}{l}\text { Student } \\
\text { Competencies }\end{array}$ & (male) & Mean & SD & & $\begin{array}{l}\text { Mean } \\
\text { (female) }\end{array}$ & SD & sig & \\
\hline 1. & Critical Thinking & 3.61 & & 0.27 & & 3.76 & 0.48 & 0.00 & \\
\hline 2. & Collaboration & 3.66 & & & $\begin{array}{l}0 \\
.44\end{array}$ & 3.86 & 0.79 & 0.09 & \\
\hline 3. & Creativity & 3.48 & & & $\begin{array}{l}0 \\
.43\end{array}$ & 3.57 & 0.54 & & 0.12 \\
\hline 4. & Communication & 3.24 & & & $\begin{array}{l}0 \\
.51 \\
\end{array}$ & 3.60 & 0 & 0.33 & \\
\hline
\end{tabular}




\begin{tabular}{lllll}
\hline & & & 69 & \\
\hline Total mean Score & 3.50 & 3.70 & 0.63 & 0.14 \\
& & 0.41 & &
\end{tabular}

The data were used to make inferences regarding the male and the female in enhancing competencies, specific critical thinking, collaboration, creativity, and communication.

When contrasting male and female students on the level of competencies on the different dimensions of the competencies. It is discovered the competencies level for female is moderately higher compared to male students. However, utlizing the independent $t$ test at $\alpha=0.05$, it was discovered that there is no statistical difference in the level of competencies in the various competencies between male and female students. Table 10 demonstrates the comparison between male and female students on the level of student competencies on the production video project. Hence, there is no significant difference among gender in collaboration, creativity and communication competency in the secondary school.

These are influenced by project-based learning frameworks and hence the impact of formal instruction is understandable. Teachers should refer to the proposed a framework on project-based learning before teaching it themselves, and that it would assist other teachers to plan tasks for students. Research data collected from Malaysia secondary school was used for the development of the framework, these shows that the proposed framework can be use in Malaysia secondary school, as a quality framework of successful research product. This is consistent with Sudjimat research which indicates PBL model can improve various facets of generic skills that include vocational students communication skills, teamwork, problem solving.(Sudjimat, 2016) A framework on PBL practice will contribute towards quality of teaching and learning for teachers and students. The Framework contributes towards productive way of competencies achievement. The framework serves as a reference to facilitate the relevant policy making and contribute to secondary school education. This study also contributes to the comprehension on how PBL should be executed in the classrooms to urge students to pursue STEAM at the high level

\section{Conclusions}

Implementation of PBL framework in the production of video project of secondary school has been implemented by student based on their perception to the understanding of the PBL framework, as well as to the possible of PBL framework enhancing the competencies of the students. According to the study result, it could be determined that PBL integrating technology develop communication, collaboration, critical thinking and creativity of secondary students. Moreover, it is relation with learning outcome expectation of Malaysia future secondary education.

Teachers should use methods that are proven effective through the framework of 21st Century Learning based on scientific research, which offers guidelines for how to prepare learners with the skills they need in the 21 st century education.

Digital video production as a critical and open dialogue tool to create by conversations to deepen understanding on diversity topics. Digital video production will support them in the expression of their considerate about the subject matter. As previous study, Prensky (Masino \& Niño-Zarazúa, 2016) asserted, the education systems and the learning processes of the student should be revised accordingly, considering that the minds and perception structures of the student, who have been born into technology, have changed too. Spin offs of this project can include project-based educational practices that prepare the students for future market demands and leverage graduate student experience and knowledge to collaboratively develop innovative pathways to student success. Education and the arrangements that encourage the procedure of innovation and knowledge creation have profound effects on the long-run economic development and improvement designs. (Masino \& Niño-Zarazúa, 2016)

\section{References}

Dole, S., Bloom, L., Kowalske, K., Dole, S., Bloom, L., Kowalske, K., \& Carolina, W. (2016). Transforming Pedagogy: Changing Perspectives from Teacher-Centered to Learner-Centered The Interdisciplinary Journal of Problem-based Learning Transforming Pedagogy: Changing Perspectives from TeacherCentered to Learner-Centered. The Interdisciplinary Journal of Problem-Based Learning, 10(1).

Edmunds, J., Arshavsky, N., Glennie, E., Charles, K., \& Rice, O. (2017). The Relationship Between Project-Based Learning and Rigor in STEM-Focused High Schools. Interdisciplinary Journal of Problem-Based Learning, 11(1), 1-6. https://doi.org/10.7771/1541-5015.1618

Framework for High Quality Project Based Learning. (2017).

Hendry, A., Hays, G., Challinor, K., \& Lynch, D. (2017). Undertaking educational research following the 
introduction, implementation, evolution, and hybridization of constructivist instructional models in an Australian PBL high school. Interdisciplinary Journal of Problem-Based Learning, 11(2), 7-10. https://doi.org/10.7771/1541-5015.1688

Hixson, N., Ravitz, J., Whisman, A., \& Hixson, Nate; Ravitz, Jason; Whisman, A. (2012). Extended Professional Development in Project-Based Learning: Impacts on 21st century teaching and student achievement, (September 2012), 94. https://doi.org/10.1016/S0025-326X(99)00075-2

Malaysia Education Blueprint, M. (2013). Malaysia Education Blueprint 2013 - 2025. Education, 27(1), 1-268. https://doi.org/10.1016/j.tate.2010.08.007

Masino, S., \& Niño-Zarazúa, M. (2016). What works to improve the quality of student learning in developing countries? International Journal of Educational Development, 48, 53-65. https://doi.org/10.1016/j.ijedudev.2015.11.012

Nayan, N., Mahat, H., Hashim, M., Saleh, Y., \& Norkhaidi, S. B. (2018). Verification of the Instrument of Climate Literacy Knowledge among Future Teachers: Confirmatory Factor Analysis (CFA). International Journal of Academic Research in Progressive Education and Development, 7(3), 26-39. https://doi.org/10.6007/IJARPED/v7-i3/4183

Petersen, C., \& Nassaji, H. (2016). Project-Based Learning through the Eyes of Teachers and Students in Adult ESL Classrooms. Canadian Modern Language Review. https://doi.org/10.3138/cmlr.2096

Pirhonen, J., \& Rasi, P. (2017). Student-generated instructional videos facilitate learning through positive emotions. Journal of Biological Education, 51(3), 215-227. https://doi.org/10.1080/00219266.2016.1200647

Rasi, P. M., \& Poikela, S. (2016). A Review of Video Triggers and Video Production in Higher Education and Continuing Education PBL Settings. Interdisciplinary Journal of Problem-Based Learning, 10(1), 5-6. https://doi.org/10.7771/1541-5015.1609

Soparat, S., Arnold, S. R., \& The, S. (2015). The Development of Thai Learners' Key Competencies by Projectbased Learning Using ICT The Development of Thai Learners' Key Competencies by Project -based Learning Using ICT. International Journal of Research in Education and Science (IJRES), Volume 1,.

Sudjimat, D. A. (2016). Implementation of project based learning model in mechanical machining skills package of vocational high school. AIP Conference Proceedings, 1778. https://doi.org/10.1063/1.4965758

Wan Mohamed, W. A., \& Omar, B. (2010). Through Work-Based Learning Among Community College. Journal of Technical Education and Training (JTET), 2(1), 1-8. 